\title{
Postoperative Complications Predict Long-term Outcome After Curative Resection for Perforated Colorectal Cancer
}

\author{
SHINTARO HASHIMOTO, KIYOAKI HAMADA, YORIHISA SUMIDA, MASATO ARAKI, KOUKI WAKATA, \\ TOTA KUGIYAMA, AYAKO SHIBUYA, MASATO NISHIMUTA, SHIGEYUKI MORINO, \\ MASAYUKI BABA, SOICHIRO KIYA, KEISUKE OZEKI and AKIHIRO NAKAMURA \\ Department of Surgery, Sasebo City General Hospital, Sasebo, Japan
}

\begin{abstract}
Background/Aim: Perforation and postoperative complications have a negative effect on long-term outcomes in patients with colorectal cancer $(C R C)$. The aim of this study was to evaluate the clinical factors with special reference to postoperative complications predicting the long-term outcome in those for whom curative resection for perforated CRC was performed. Patients and Methods: Patients who underwent curative resection for perforated CRC at stage II or III from April 2003 to March 2020 were included. Clinical factors were retrospectively analyzed. Results: Forty-four patients met the selection criteria. The 30-day mortality rate was $4.5 \%$ and the complication rate was $47.7 \%$. Excluding 30-day mortality, five-year recurrence-free survival (RFS) and overall survival (OS) were $62.3 \%$ and $73.6 \%$, respectively. Multivariate analysis showed that postoperative complications $(p=0.005)$ and pT4 pathological factor $(p=0.009)$ were independent prognostic factors for RFS. Only postoperative complications $(p=0.023)$ were an independent prognostic factor for OS. Conclusion: Postoperative complications were significantly associated with RFS and OS, and pT4 was associated with RFS. The prevention and management of postoperative adverse events may be important for perforated CRC.
\end{abstract}

Perforated colorectal cancer (CRC) is complicated by both septic and oncological problems. Fecal leakage causes peritonitis, and in many cases emergent surgical procedures are required (1). In addition, extensive lymph node dissection is also necessary (2). After recovering from sepsis, patients

This article is freely accessible online.

Correspondence to: Kiyoaki Hamada, Department of Surgery, Sasebo City General Hospital, 9-3 Hirase, Sasebo, Nagasaki 8578511, Japan. Tel: +81 956241515, Fax: +81 956224641, e-mail: tywsr220@yahoo.co.jp

Key Words: Colorectal cancer, colorectal cancer perforation, intestinal perforation. confront both a high rate of recurrence and poor survival. The long-term outcome of perforated CRC patients was reported to be poor compared with CRC without perforation (2-6).

Postoperative complications reportedly result in poor outcomes after resection of $\mathrm{CRC}(7,8)$. Adjuvant chemotherapy is recommended for stage III and high-risk stage II disease (9); however, postoperative complications lead to delays in adjuvant chemotherapy (10). The prognostic factors that affect long-term survival and recurrence after curative resection for perforated CRC are unclear. Furthermore, the relationship between postoperative complications and longterm outcome has been rarely reported.

The aim of this study was to review clinical data of perforated CRC and evaluate various clinical factors with special reference to postoperative complications predicting the long-term outcome of patients who underwent curative resection for perforated CRC.

\section{Patients and Methods}

We performed a retrospective review of medical records of consecutive patients who underwent primary curative tumor resection for perforated CRC from April 2003 to March 2020 at Sasebo City General Hospital. Patients who experienced perforation after intubation of a transanal drainage tube $(n=11)$, from a selfexpandable metallic stent $(n=2)$, during colonoscopy $(n=2)$, or during chemotherapy $(n=2)$, or who had appendiceal cancer perforation $(n=2)$ were excluded. Only adenocarcinomas were included. Finally, 44 patients were included in the analysis. This retrospective study was approved by the institutional review board of the participating hospital, and informed consent was waived. The ethics approval number was 2020-A019.

We reviewed and recorded the following data: sex, age, American Society of Anesthesiologists Physical Status (ASA-PS), tumor location, presence or absence of emergent surgery, site of perforation, type of surgery, extent of lymph node dissection, histological type, pathological $\mathrm{T}$ stage, pathological $\mathrm{N}$ stage, lymphovascular invasion, number of dissected lymph nodes, postoperative complications, adjuvant chemotherapy, local recurrence, distant metastasis, and survival time.

The tumor stage was classified according to tumor-nodemetastasis (TNM) classification (11). Postoperative complications 
Table I. Clinical characteristics of perforated colorectal cancer patients.

\begin{tabular}{|c|c|}
\hline Number & 44 \\
\hline Gender, male & $19(43.2)$ \\
\hline Age (years, range) & $76(42-88)$ \\
\hline \multicolumn{2}{|l|}{ ASA PS } \\
\hline I-II & $26(59.1)$ \\
\hline III-IV & $18(40.9)$ \\
\hline \multicolumn{2}{|l|}{ Location of tumor } \\
\hline Cecum & $3(6.8)$ \\
\hline Ascending colon & $4(9.1)$ \\
\hline Transverse colon & $5(11.4)$ \\
\hline Descending colon & $0(0.0)$ \\
\hline Sigmoid colon & $24(54.5)$ \\
\hline Rectum & $6(13.6)$ \\
\hline \multicolumn{2}{|l|}{ Site of perforation } \\
\hline Proximal site & $13(29.5)$ \\
\hline Cancer site & $31(70.5)$ \\
\hline Emergent surgery & $35(81.8)$ \\
\hline \multicolumn{2}{|l|}{ Treatment } \\
\hline Resection and stoma construction & $25(56.8)$ \\
\hline Resection+anastomosis with temporary stoma & $2(4.5)$ \\
\hline Resection+anastomosis without temporary stoma & $17(38.6)$ \\
\hline 30 days mortality & $2(4.5)$ \\
\hline \multicolumn{2}{|l|}{ Pathologic status } \\
\hline Well differentiated & $19(43.2)$ \\
\hline Moderately differentiated & $22(50.0)$ \\
\hline Poorly differentiated & $2(4.5)$ \\
\hline Mucinous & $1(2.3)$ \\
\hline \multicolumn{2}{|l|}{ Pathological T stage } \\
\hline pT1-pT2 & $0(0.0)$ \\
\hline pT3 & $25(56.8)$ \\
\hline pT4 & $19(43.2)$ \\
\hline \multicolumn{2}{|l|}{ Stage } \\
\hline Stage II & $33(75.0)$ \\
\hline Stage III & $11(25.0)$ \\
\hline \multicolumn{2}{|l|}{ Lymphovascular invasion } \\
\hline Negative & $9(20.5)$ \\
\hline Positive & $35(79.5)$ \\
\hline
\end{tabular}

Data are number (\%) or medians (range). ASA-PS; The American Society of Anesthesiologists Physical Status; CD, Clavien-Dindo classification.

were defined as complications that occurred within 30 days of the primary surgery. Patients with Clavien-Dindo grade 2 or higher complications were included in the complications group (12). Tumor location was classified as colon (cecum to rectosigmoid colon) and rectum. The site of perforation was divided into two groups: perforation of normal mucosa at the proximal side of the tumor and cancer site perforation (13).

Statistical analyses were performed using Bell Curve for Excel software, version 2.02 (Social Survey Research Information Co., Ltd., Tokyo, Japan). The data are presented as median values with ranges. Continuous data were compared using the Student's $t$-test, and categorical data were compared using Fisher's exact test or the chi-squared test, as appropriate. Five-year recurrence-free survival (RFS) and overall survival (OS) were calculated according to the Kaplan-Meier method. Patients who died within 30 days after surgery were excluded from the analysis of long-term outcomes. OS
Table II. Postoperative complications (CD grade 2-5).

$\begin{array}{lc}\text { Postoperative complication (CD Grade 2-5) } & \\ \text { Yes } & 21(47.7) \\ \text { No } & 23(52.3) \\ \text { Specific complications } & \\ \text { CD Grade 2 } & 10(22.7) \\ \text { Wound infection } & 6(13.6) \\ \text { Prolonged ileus } & 4(9.1) \\ \text { Heart failure } & 1(2.3) \\ \text { CD Grade 3 } & 8(18.2) \\ \text { Intraabdominal abscess } & 4(9.1) \\ \text { Wound infection } & 2(4.5) \\ \text { Stoma necrosis } & 1(2.3) \\ \text { Pneumonia } & 1(2.3) \\ \text { CD Grade 4 } & 1(2.3) \\ \text { Prolonged sepsis } & 1(2.3) \\ \text { CD Grade 5 } & 2(4.5) \\ \text { Prolonged sepsis } & 2(4.5)\end{array}$

$\mathrm{CD}$, Clavien-Dindo classification.

was defined as the duration from surgery to death or last follow-up. RFS was defined as the duration from surgery to cancer recurrence.

Multivariate analysis using a Cox hazards model was performed to identify the independent risk factors for OS. All variables related to the risk of RFS or OS with a $p$-value $<0.10$ on univariate analysis were included in the multivariate analysis. All $p$-values of $<0.05$ were considered significant.

\section{Results}

Table I shows the clinicopathological characteristics of 44 patients. The study population included 19 male (43.2\%) and 25 female $(56.8 \%)$ patients, with a median age of 76 (range $=42-88)$ years. Among these patients, $18(42.9 \%)$ had a poor performance status (ASA-PS $\geq 3$ ). Most had colon cancer $(\mathrm{n}=38,86.4 \%)$, and sigmoid colon cancer accounted for the majority of patients. Thirteen patients $(29.5 \%)$ had the perforation site at the oral site of the cancer and the rest experienced perforation at the cancer site. Most patients $(\mathrm{n}=35,81.8 \%)$ underwent emergent surgery defined as surgery performed within 24 hours from hospital admission. Twenty-five patients (56.8\%) underwent tumor resection and stoma construction. Two patients (4.5\%) underwent resection and anastomosis with temporary stoma construction and 17 patients $(38.6 \%)$ received resection without stoma construction. Histopathologically, 19 patients (43.2\%) were diagnosed as pathological T4 (pT4). Eleven (25.0\%) patients had stage III disease (25.0\%). Most patients had lymphovascular invasion $(\mathrm{n}=35,79.5 \%)$. Thirty-day mortality was $4.5 \% \quad(n=2)$. Eighteen patients $(40.9 \%)$ received adjuvant chemotherapy.

Table II shows the postoperative complications. The overall postoperative complication rate $(\mathrm{CD} \geq 2)$ was $47.7 \%(\mathrm{n}=21)$. 

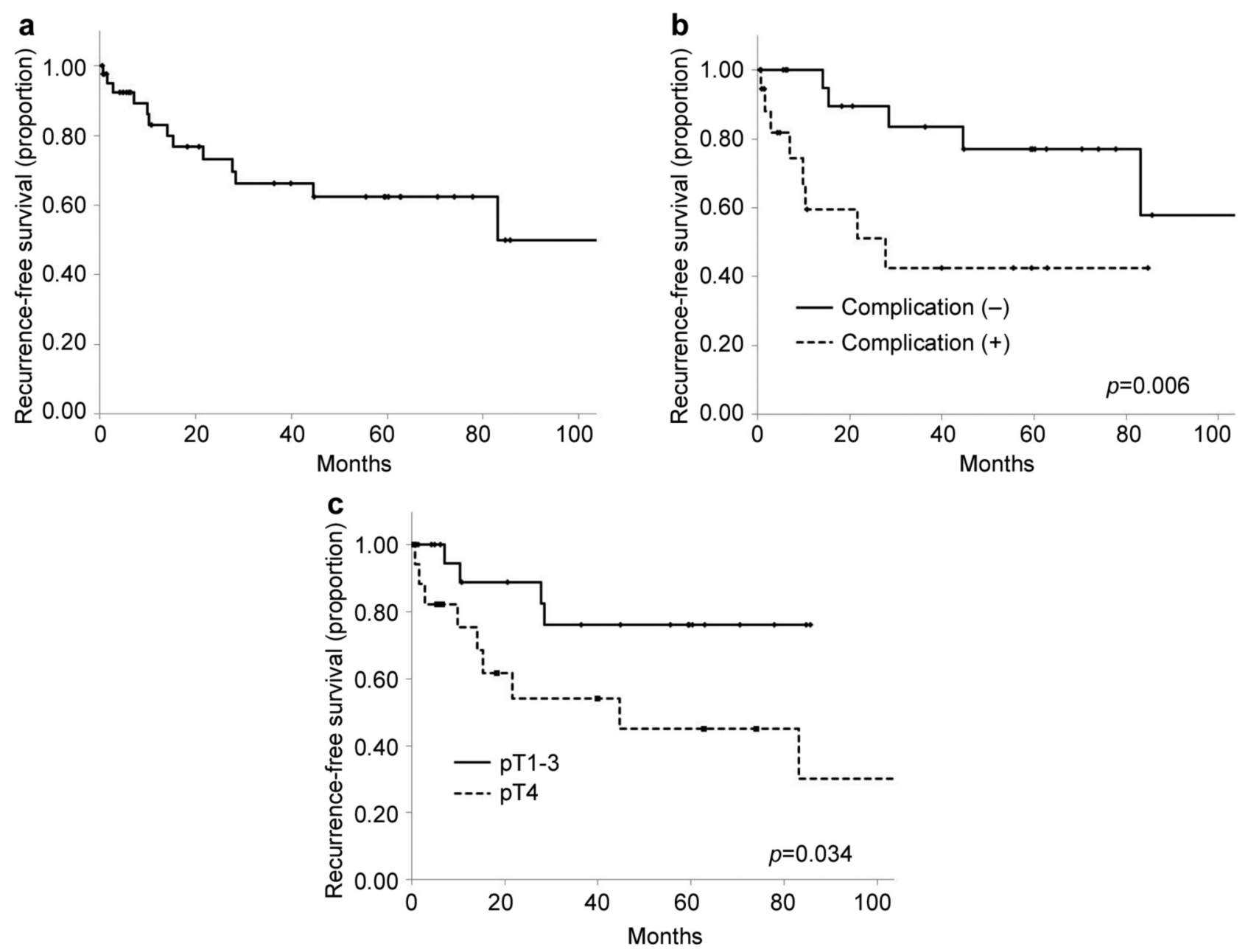

Figure 1. Recurrence-free survival (RFS) estimates (a), according to the presence or absence of postoperative complications (b), and pT1-3 vs. pT4 (c).

Among 21 patients with morbidities, 10 (22.7\%) had grade II complications, including wound infection $(n=6,13.6 \%)$, prolonged ileus $(n=4,9.1 \%)$, and heart failure $(n=1,2.3 \%)$. Eight patients (18.2\%) had grade III complications, including intraabdominal abscess $(n=4,9.1 \%)$, wound infection $(n=2$, $4.5 \%)$, stoma necrosis $(n=1,2.3 \%)$, and pneumonia $(n=1$, $2.3 \%)$. One patient $(2.3 \%)$ had grade IV prolonged sepsis and two patients (4.5\%) experienced postoperative death within 30 days related to prolonged sepsis (grade V).

Table III shows the clinical differences between patients with and without postoperative complications. There were no significant differences in sex, age, ASA-PS, emergent surgery, site of perforation, type of surgery, pathological $\mathrm{T}$ stage, stage, and adjuvant chemotherapy. The rate of rectal cancer was higher in the postoperative complications group.

Among 42 patients, excluding two patients who experienced 30-day mortality, the median follow-up period of the present study was 41 months (range=0-190 months).
Thirteen patients experienced recurrence including peritoneal dissemination $(n=4)$, liver metastasis $(n=3)$, lung metastasis $(n=3)$, lymph node metastasis $(n=2)$, and ovarian metastasis $(n=1)$. The 5 -year actuarial RFS was $62.3 \%$ (Figure 1a). RFS was poor in the postoperative complications group ( $p=0.006$; Figure $1 \mathrm{~b})$ and in pT4 patients ( $p=0.034$; Figure 1c). Table IV shows the results of univariate and multivariate analyses of risk factors for RFS. Postoperative complications $(p=0.027)$ and pT4 $(p=0.046)$ were significantly associated with RFS on univariate analysis. Multivariate analysis showed that postoperative complications $(\mathrm{OR}=5.720 ; 95 \% \mathrm{CI}=1.695-19.305 ; p=0.005)$ and pT4 $(\mathrm{OR}=5.226 ; 95 \% \mathrm{CI}=1.518-18.000 ; p=0.009)$ were independent prognostic factors for RFS.

The 5-year OS was $73.6 \%$ (Figure 2a). OS was poor in the postoperative complications group ( $p=0.019$; Figure $2 b$ ) and in patients who did not receive adjuvant chemotherapy ( $p=0.016$; Figure $2 \mathrm{c}$ ). Table $\mathrm{V}$ shows the results of univariate 

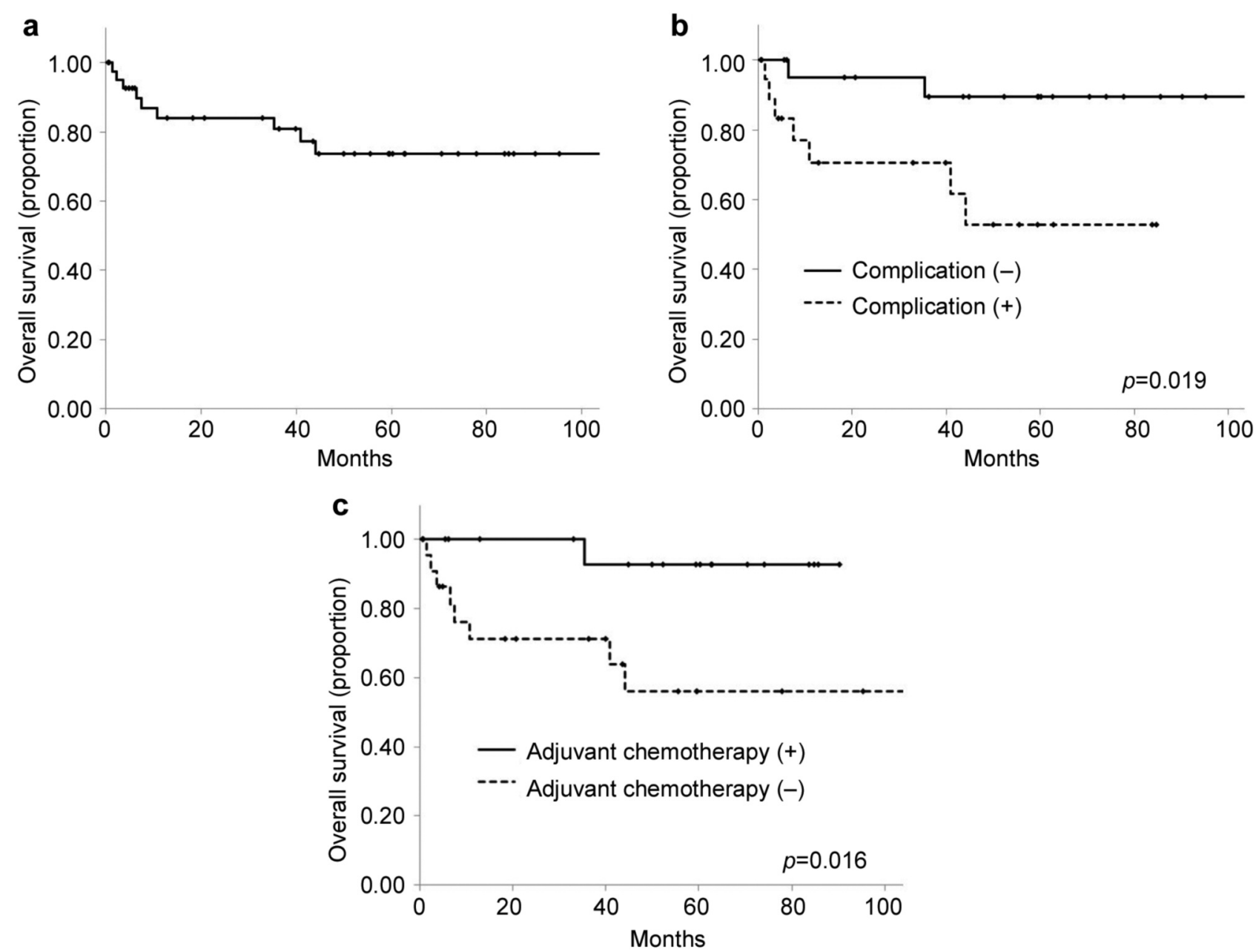

Figure 2. Overall survival (OS) estimates (a), according to the presence or absence of postoperative complications (b), and by the presence or absence of adjuvant chemotherapy (c).

and multivariate analyses of risk factors for OS. Postoperative complications $(p=0.034)$ and adjuvant chemotherapy $(p=0.044)$ were significantly associated with OS on univariate analysis. Multivariate analysis showed that only postoperative complications $(\mathrm{OR}=6.627 ; 95 \%$ $\mathrm{CI}=1.304-33.683, p=0.023)$ was an independent prognostic factor for OS.

\section{Discussion}

This single center retrospective study investigated the longterm outcomes of perforated CRC patients who underwent primary curative tumor resection. Postoperative complications and pT4 were independent risk factors for poor RFS. Furthermore, postoperative complications were an independent risk factor for poor OS.

Perforated CRC patients face the life-threatening conditions of both malignant disease and sepsis (1). These patients often require emergent surgery (1), with perioperative mortality ranging between $11 \%-21 \%$ (13-18). Furthermore, even after perforated CRC patients recover from peritonitis and the perioperative phase, colorectal perforation is reported to be a risk factor for poor prognosis $(2-5)$ and high recurrence $(3,6)$. This high recurrence rate is reported to be associated with the dissemination of cancer cells due to perforation and reduced lymph node dissection (13).

Postoperative complications after resection of CRC have been reported to be a factor associated with worse survival and a higher recurrence rate $(7,8)$ and the relationship between postoperative complications after curative perforated CRC and long-term outcome have been rarely reported.

In the current study, the rate of postoperative complications was $47.7 \%$ and included eight cases of wound infection, eight cases of intraabdominal complications including stoma, and five cases associated with general condition. Although the severity of the tumor and the general 
Table III. Comparison of clinical characteristics between perforated colon cancer patients with postoperative complications $(C D \geq 2)$ and without postoperative complications $(C D<2)$.

\begin{tabular}{|c|c|c|c|}
\hline & $\begin{array}{l}\text { Postoperative } \\
\text { complications } \\
\quad(+)(\mathrm{n}=21)\end{array}$ & $\begin{array}{l}\text { Postoperative } \\
\text { complications } \\
\quad(-)(\mathrm{n}=23)\end{array}$ & $p$-value \\
\hline Gender & & & 0.361 \\
\hline Male & $11(52.4)$ & $8(34.8)$ & \\
\hline Female & $10(47.6)$ & $15(65.2)$ & \\
\hline Age (median, range) & $76(42-78)$ & $71(45-87)$ & 0.509 \\
\hline ASA-PS & & & 0.541 \\
\hline I-II & $11(52.4)$ & $15(65.2)$ & \\
\hline III-IV & $10(47.6)$ & $8(34.8)$ & \\
\hline Location of tumor & & & 0.042 \\
\hline Colon & $15(71.4)$ & $22(95.7)$ & \\
\hline Rectum & $6(28.6)$ & $1(4.3)$ & \\
\hline Emergent surgery & & & 0.701 \\
\hline Yes & $18(85.7)$ & $18(78.3)$ & \\
\hline No & $3(14.3)$ & $5(21.7)$ & \\
\hline Site of perforation & & & 0.130 \\
\hline Proximal site & $8(38.1)$ & $15(65.2)$ & \\
\hline Cancer site & $13(61.9)$ & $8(34.8)$ & \\
\hline Type of surgery & & & $>.999$ \\
\hline Anastomosis (+) & $9(42.9)$ & $10(43.5)$ & \\
\hline Anastomosis (-) & $12(57.1)$ & $13(56.5)$ & \\
\hline Pathological T stage & & & 0.557 \\
\hline pT1-3 & 13 (61.9) & $12(52.2)$ & \\
\hline pT4 & $8(38.1)$ & $11(47.8)$ & \\
\hline Stage & & & 0.303 \\
\hline Stage II & $7(33.3)$ & $4(17.4)$ & \\
\hline Stage III & $14(66.7)$ & $19(82.6)$ & \\
\hline Lymphovascular invasion & & & $>.999$ \\
\hline Yes & $17(81.0)$ & $18(78.3)$ & \\
\hline No & $4(19.0)$ & $5(21.7)$ & \\
\hline Adjuvant chemotherapy & & & 0.136 \\
\hline Yes & $6(28.6)$ & $12(52.2)$ & \\
\hline No & $15(71.4)$ & $11(47.8)$ & \\
\hline
\end{tabular}

ASA-PS, The American Society of Anesthesiologists Physical Status; $\mathrm{CD}$, Clavien-Dindo classification.

performance status could affect the long-term outcome, excluding two cases of postoperative mortality, there was no difference between with or without complications except for the location of the tumor.

Adjuvant chemotherapy is recommended for stage III and high-risk stage II disease, including perforated CRC patients (9). Meanwhile, postoperative complications are associated with delays in adjuvant chemotherapy (10) and these delays lead to worse RFS and OS (19). In this study, there was no difference in RFS and OS between the cases with and without adjuvant chemotherapy on multivariate analysis; however, the delay in postoperative chemotherapy tended to be more than 8 weeks in the postoperative group (3/6 (50\%) vs. $1 / 12(8.3 \%) ; p=0.080)$. This delay in adjuvant chemotherapy might have affected the long-term outcome.
Table IV. Clinical factors predicting RFS after curative resection of perforated colorectal cancer.

\begin{tabular}{|c|c|c|c|c|}
\hline & $\begin{array}{c}\text { Univariate } \\
\text { analysis }\end{array}$ & & $\begin{array}{l}\text { Multivariate } \\
\text { analysis }\end{array}$ & \\
\hline & $p$-Value & HR & $95 \% \mathrm{CI}$ & $p$-Value \\
\hline $\begin{array}{l}\text { Gender } \\
\text { Male } \\
\text { Female }\end{array}$ & 0.746 & & & \\
\hline $\begin{array}{l}\text { Age, years } \\
\geq 70 \\
<70\end{array}$ & 0.778 & & & \\
\hline $\begin{array}{l}\text { ASA-PS } \\
1-2 \\
\geq 3\end{array}$ & 0.346 & & & \\
\hline $\begin{array}{l}\text { Tumor location } \\
\text { Colon } \\
\text { Rectum }\end{array}$ & 0.934 & & & \\
\hline $\begin{array}{l}\text { Emergent surgery } \\
\text { Yes } \\
\text { No }\end{array}$ & 0.768 & & & \\
\hline $\begin{array}{l}\text { Site of perforation } \\
\text { Tumor } \\
\text { Oral }\end{array}$ & 0.365 & & & \\
\hline $\begin{array}{l}\text { Central node dissection } \\
\text { Yes } \\
\text { No }\end{array}$ & 0.116 & & & \\
\hline $\begin{array}{l}\text { Lymph node sampled } \\
\quad \geq 12 \\
\quad<12\end{array}$ & 0.706 & & & \\
\hline Pathological T stage & 0.046 & & & 0.009 \\
\hline $\begin{array}{l}\text { pT1-3 } \\
\text { pT4 }\end{array}$ & & $\begin{array}{c}1 \\
5.226\end{array}$ & $1.518-18.000$ & \\
\hline $\begin{array}{c}\text { Stage } \\
\text { I-II } \\
\text { III }\end{array}$ & 0.408 & & & \\
\hline $\begin{array}{l}\text { Lymphovascular invasion } \\
\text { Yes } \\
\text { No }\end{array}$ & 0.462 & & & \\
\hline $\begin{array}{l}\text { Postoperative complication } \\
(\mathrm{CD} \geq 2)\end{array}$ & 0.027 & & & 0.005 \\
\hline Yes & & 5.720 & $1.695-19.305$ & \\
\hline No & & 1 & & \\
\hline $\begin{array}{l}\text { Adjuvant chemotherapy } \\
\text { Yes } \\
\text { No }\end{array}$ & 0.854 & & & \\
\hline
\end{tabular}

HR, Hazard ratio; CI, confidence interval; ASA-PS, The American Society of Anesthesiologists Physical Status; CD, Clavien-Dindo classification.

The results of our study suggest that complications of surgery for perforated CRC may affect both short- and long-term cancer outcomes. This research also revealed that pT4 is associated with the high recurrence rate. Previous research revealed several risk factors for the long-term outcome of perforated CRC. Lymph node metastasis $(3,14)$ and oral site perforation, compared with cancer site 
Table V. Clinical factors predicting OS of curative resection of perforated colorectal cancer.

\begin{tabular}{|c|c|c|c|c|}
\hline & \multirow{2}{*}{$\begin{array}{c}\begin{array}{c}\text { Univariate } \\
\text { analysis }\end{array} \\
p \text {-Value }\end{array}$} & \multicolumn{3}{|c|}{$\begin{array}{l}\text { Multivariate } \\
\text { analysis }\end{array}$} \\
\hline & & HR & $95 \% \mathrm{CI}$ & $p$-Value \\
\hline $\begin{array}{l}\text { Gender } \\
\text { Male } \\
\text { Female }\end{array}$ & 0.534 & & & \\
\hline $\begin{array}{l}\text { Age, years } \\
\geq 70 \\
<70\end{array}$ & 0.124 & & & \\
\hline ASA-PS & 0.054 & & & 0.141 \\
\hline $1-2$ & & 1 & & \\
\hline$\geq 3$ & & 3.016 & $0.693-13.125$ & \\
\hline $\begin{array}{l}\text { Tumor location } \\
\text { Colon } \\
\text { Rectum }\end{array}$ & 0.574 & & & \\
\hline $\begin{array}{l}\text { Emergent surgery } \\
\text { Yes } \\
\text { No }\end{array}$ & 0.612 & & & \\
\hline $\begin{array}{l}\text { Site of perforation } \\
\text { Tumor } \\
\text { Oral }\end{array}$ & 0.547 & & & \\
\hline $\begin{array}{l}\text { Central node dissection } \\
\text { Yes } \\
\text { No }\end{array}$ & 0.569 & & & \\
\hline $\begin{array}{l}\text { Lymph node sampled } \\
\quad \geq 12 \\
\quad<12\end{array}$ & 0.699 & & & \\
\hline $\begin{array}{l}\text { Pathological T stage } \\
\text { T1-3 } \\
\text { T4 }\end{array}$ & 0.141 & & & \\
\hline $\begin{array}{l}\text { Stage } \\
\text { I-II } \\
\text { III }\end{array}$ & 0.929 & & & \\
\hline $\begin{array}{l}\text { Lymphovascular invasion } \\
\text { Yes } \\
\text { No }\end{array}$ & 0.445 & & & \\
\hline $\begin{array}{l}\text { Postoperative complication } \\
(\mathrm{CD} \geq 2)\end{array}$ & 0.034 & & & 0.023 \\
\hline Yes & & 6.627 & $1.304-33.683$ & \\
\hline No & & 1 & & \\
\hline Adjuvant chemotherapy & 0.044 & & & 0.143 \\
\hline Yes & & 1 & & \\
\hline No & & 3.016 & $0.693-13.125$ & \\
\hline
\end{tabular}

HR, Hazard ratio; CI, confidence interval; ASA-PS, The American Society of Anesthesiologists Physical Status; CD, Clavien-Dindo classification.

perforation (14), were reported to be risk factors for poor OS and RFS. Insufficient lymph node dissection (2), pathological stage (20), and free perforation compared to contained perforation (18), were reported to be associated with poor OS. Although perforated CRC requires a short surgical time from the viewpoint of emergent surgery with sepsis, extensive lymph node dissection is required to improve the long-term outcome. In these years the longterm outcome of colorectal cancer is reported to be poor in right-sided cancer compared to left-sided (21). In this study, there was no statistical differences in 5-year OS (rightsided, $77.8 \%$ vs. left-sided, 71.8\%; $p=0.910)$ and RFS (right-sided, 63.5\% vs. left-sided, 62.2\%; $p=0.883$ ). Regarding anastomosis, primary anastomosis with or without ileostomy was reported to be equivalent in perforated diverticulitis, but not cancer perforation (22). The safety of primary anastomosis for perforated CRC is controversial. Thus, simple surgical procedures should be considered to reduce postoperative complications and to prevent a delay in adjuvant chemotherapy.

Regarding strengths and weaknesses of this study, the present study had several limitations. First, relatively few patients were evaluated and the study design was retrospective. Because of the low incidence of the disease, reportedly 2.6$10 \%$ among CRC patients (1), it is hard to recruit many patients. Further prospective studies in larger cohort are needed to further confirm our results. Second, the surgical procedure and induction of postoperative adjuvant chemotherapy were dependent on the surgeons and cases. Third, there might be a time bias as the data in this study were collected over a relatively long period. During this time, the surgical procedures and postoperative treatment might have changed.

The strength of this study is that our cohort included only consecutive patients who experienced curative resection for perforated CRC. Long-term outcome and the analysis of the risk factor of poor OS and RFS after resection for perforated $\mathrm{CRC}$ is limited and this result can be a valuable report.

In conclusion, postoperative complications and pT4 were associated with RFS, and postoperative complications also increased the risk of poor OS. The prevention and management of postoperative adverse events may be important to improve RFS and OS for perforated CRC.

\section{Conflicts of Interest}

None of the Authors has any financial interest related to this study.

\section{Authors' Contributions}

Shintaro Hashimoto and Kiyoaki Hamada were responsible for the study concept. Shintaro Hashimoto, Kiyoaki Hamada, Araki Masato, Yorihisa Sumida, Koki Wakata, Tota Kugiyama, Ayako Sibuya, Masato Nishimuta, Shigeyuki Morino, Masayuki Baba, Soichiro Kiya, and Keisuke Ozeki collaborated in the patients' medical care. Yorihisa Sumida and Akihiro Nakamura reviewed the manuscript. All Authors approved the final article.

\section{Acknowledgements}

The Authors would like to thank H. Nikki March, Ph.D., from Edanz Group (https://en-author-services.edanzgroup.com/ac) for editing a draft of this manuscript. 


\section{References}

1 Otani K, Kawai K, Hata K, Tanaka T, Nishikawa T, Sasaki K, Kaneko M, Murono K, Emoto K and Nozawa H: Colon cancer with perforation. Surg Today 49: 15-20, 2019. PMID: 29691659. DOI: $10.1007 / \mathrm{s} 00595-018-1661-8$

2 Sugawara K, Kawaguchi Y, Nomura Y, Koike D, Nagai M and Tanaka N: Insufficient lymph node sampling in patients with colorectal cancer perforation is associated with an adverse oncological outcome. World J Surg 41(1): 295-305, 2017. PMID: 27464912. DOI: 10.1007/s00268-016-3667-y

3 Griffin MR, Bergstralh EJ, Coffey RJ, Beart RW Jr and Melton LJ $3^{\text {rd: }}$ Predictors of survival after curative resection of carcinoma of the colon and rectum. Cancer 60(9): 2318-2324, 1987. PMID: 3440238. DOI: 10.1002/1097-0142(19871101)60:9<2318::aidcncr2820600934>3.0.co;2-b

4 Chen HS and Sheen-Chen SM: Obstruction and perforation in colorectal adenocarcinoma: An analysis of prognosis and current trends. Surgery 127(4): 370-376, 2000. PMID: 10776426. DOI: 10.1067/msy.2000.104674

5 Mandava, N, Kumar S, Pizzi W F and Aprile I J: Perforated colorectal carcinomas. Am J Surg 172(3): 236-238, 1996. PMID: 8862074. DOI: 10.1016/s0002-9610(96)00164-x

6 Ho YH, Siu SK, Buttner P, Stevenson A, Lumley J and Stitz R: The effect of obstruction and perforation on colorectal cancer disease-free survival. World J Surg 34: 1091-101, 2010. PMID: 20151132. DOI: 10.1007/s00268-010-0443-2

7 Aoyama T, Oba K, Honda M, Sadahiro S, Hamada C, Mayanagi S, Kanda M, Maeda H, Kashiwabara K, Sakamoto J, Saji S and Yoshikawa T: Impact of postoperative complications on the colorectal cancer survival and recurrence: analyses of pooled individual patients' data from three large phase III randomized trials. Cancer Med 6(7): 1573-80, 2017. PMID: 28639738. DOI: $10.1002 / \mathrm{cam} 4.1126$

8 Wai LL, Hok KC, Yee ML and Judy WH: The impact of postoperative complications on long-term outcomes following curative resection for colorectal cancer. Ann Surg Oncol 14(9): 2559-2566, 2007. PMID: 17522945. DOI: 10.1245/s10434-0079434-4

9 Benson AB 3rd, Schrag D, Somerfield MR, Cohen AM, Figueredo AT, Flynn PJ, Krzyzanowska MK, Maroun J, McAllister P, Cutsem EV, Brouwers M, Charette M and Haller DG: American society of clinical oncology recommendations on adjuvant chemotherapy for stage II colon cancer. J Clin Oncol 22(16): 3408-3419, 2004. PMID: 15199089. DOI: 10.1200/ JCO.2004.05.063

10 Hendren S, Birkmeyer JD, Yin H, Banerjee M, Sonnenday C and Morris AM: Surgical complications are associated with omission of chemotherapy for stage III colorectal cancer. Dis Colon Rectum 53(12): 1587-1593, 2010. PMID: 21178851. DOI: 10.1007/DCR.0b013e3181f2f202

11 Brierley JD and Gospodarowicz MK: TNM classification of malignant tumours. C.Wittekind (eds.). New York, John Wiley \& Sons, 2017.

12 Dindo D, Demartines N and Clavien PA: Classification of surgical complications: a new proposal with evaluation in a cohort of 6336 patients and results of a survey. Ann Surg 240(2): 205-213, 2004. PMID: 15273542. DOI: 10.1097/01 sla.0000133083.54934.ae
13 Asano H, Kojima K, Ogino N, Fukano H, Ohara Y and Shinozuka N: Postoperative recurrence and risk factors of colorectal cancer perforation. Int J Colorectal Dis 32(3): 419424, 2017. PMID: 27796497. DOI: 10.1007/s00384-016-2694-3

14 Lee IK, Sung NY, Lee YS, Lee SC, Kang WK, Cho HM, Ahn $\mathrm{CH}$, Lee DS, Oh ST, Kim JG, Jeon HM and Chang SK: The survival rate and prognostic factors in 26 perforated colorectal cancer patients. Int J Colorectal Dis 22(5): 467-473, 2007. PMID: 16947042. DOI: 10.1007/s00384-006-0184-8

15 Kaya S, Seker A, Altin O, Altuntas YE, Kaptanoglu L, Kement M, Bildik N, Küçük $\mathrm{H}$ : Evaluation of current therapeutic approach to obstructive and perforated colorectal cancers. Ulus Travma Acil Cerrahi Derg 25(6): 589-596, 2019. PMID: 31701493. DOI: $10.14744 /$ tjtes.2019.03828

16 Biondo S, Kreisler E, Millan M, Fraccalvieri D, Golda T, Marti Rague J and Salazar R: Differences in patient postoperative and long-term outcomes between obstructive and perforated colonic cancer. Am J Surg 195(4): 427-432, 2008. PMID: 18361923. DOI: $10.1016 /$ j.amjsurg.2007.02.027

17 Tebala GD, Natili A, Gallucci A, Brachini G, Khan AQ, Tebala $\mathrm{D}$ and Mingoli A: Emergency treatment of complicated colorectal cancer. Cancer Manag Res 10: 827-838, 2018. PMID: 29719419. DOI: $10.2147 / C M A R . S 158335$

18 Zielinski MD, Merchea A, Heller SF and You YN: Emergency management of perforated colon cancers: how aggressive should we be? J Gastrointest Surg 15(12): 2232-2238, 2011. PMID: 21913040. DOI: $10.1007 / \mathrm{s} 11605-011-1674-8$

19 Des Guetz G, Nicolas P, Perret GY, Morere JF and Uzzan B: Does delaying adjuvant chemotherapy after curative surgery for colorectal cancer impair survival? A meta-analysis. Eur J Cancer 46(6): 1049-1055, 2010. PMID: 20138505. DOI: 10.1016/ j.ejca.2010.01.020

20 Tan KK, Hong CC, Zhang J, Liu JZ and Sim R: Surgery for perforated colorectal malignancy in an Asian population: an institution's experience over 5 years. Int J Colorectal Dis 25(8): 989-995, 2010. PMID: 20390285. DOI: 10.1007/s00384-0100945-2

21 Signorelli C, Chilelli MG, Sperduti I, Giacinti S, Amodio PM, Palmieri RM, Ranalli TV, Gomes VV, Rosetto ME, Nelli M and Ruggeri EM: Correlation of tumor location to clinical outcomes in colorectal cancer: a single-institution retrospective analysis. Anticancer Res 39: 4917-4924, 2019. PMID: 31519596. DOI: 10.21873/anticanres.13679

22 Cirocchi R, Afshar S, Shaban F, Nascimbeni R, Vettoretto N, Di Saverio S, Randolph J, Zago M, Chiarugi M, Binda GA: Perforated sigmoid diverticulitis: Hartmann's procedure or resection with primary anastomosis-a systematic review and meta-analysis of randomised control trials. Tech Coloproctol 22(10): 743-753, 2018. PMID: 29995173. DOI: 10.1007/s10151018-1819-9 